\title{
Investigation of the Instability of Plasmids Directing the Expression of Met-Prochymosin in Escherichia coli
}

\author{
By CELIA A. CAULCOTT, ${ }^{*}$ GERALD LILLEY,${ }^{1} \dagger$ \\ EDWINA M. WRIGHT, 2 MARTYN K. ROBINSON²† AND \\ GEOFFREY T. YARRANTON ${ }^{2}$ \\ Departments of ${ }^{1}$ Microbial Fermentation Development and ${ }^{2}$ Microbial Genetics, Celltech Ltd, \\ 244-250 Bath Road, Slough, Berkshire SLI 4DY, UK
}

(Received 3 May 1985; revised 17 July 1985)

\begin{abstract}
The causes of the instability of a multicopy plasmid, pCT70, which directs the expression of calf prochymosin in Escherichia coli, were investigated. Plasmid pAT153 and its derivative, pCT54, were stable for more than 90 generations in continuous culture with glucose limitation. The multicopy plasmid pCT66, which expressed very low levels of prochymosin due to poor translational efficiency, and low copy number plasmids which efficiently expressed the prochymosin gene, were also stable. These results indicated that high level translation of the recombinant gene was the cause of the instability of pCT70. The maximum specific growth rate of $E$. coli(pCT70) was reduced by $30 \%$ compared with E. coli(pCT66).

To fulfil the requirements of a production system, a dual origin plasmid with controllable copy number was developed. Both this plasmid (pMGl65) and a derivative which contained the prochymosin gene (pMG168) were stable when maintained at low copy number. When the copy number of plasmid pMG168 was increased by putting replication under the control of the $\lambda \mathrm{P}_{\mathrm{R}}$ promoter and the cI857 temperature sensitive repressor, expression of prochymosin was achieved. This strategy enables large-scale production of prochymosin without the need for antibiotic selection or other methods of preventing plasmid loss.
\end{abstract}

\section{INTRODUCTION}

Cloning and expression of heterologous genes in Escherichia coli provides a mechanism by which valuable, and often difficult to obtain, proteins may be synthesized in large quantities. Using cloning vectors based on various natural $E$. coli plasmids, products such as human growth hormone (Goeddel et al., 1979), tissue plasminogen activator (Pennica et al., 1983) and Metprochymosin (Emtage et al., 1983) have been synthesized in E. coli. However, although the expression systems are frequently highly efficient, the expression vectors may be less stable than the parent cloning vectors (Imanaka et al., 1980; Miwa \& Momose, 1982; Steuber \& Bujard, 1982; Skogman et al., 1983).

The loss of plasmids from their host cells, due to defective partitioning at cell division, has been described as segregational instability (Carrier et al., 1983). The segregational stability of various plasmids such as pAT153 and pBR322 in E. coli has been investigated by several groups. The results observed with both these, and other, plasmids do not present a coherent picture as to the cause of segregational instability. Host strain variation is likely to explain some of the differences in stability of both pAT153 (Primrose et al., 1984; Jones, S. et al., 1980; results in this paper) and pBR322 (Noack et al., 1981; Jones, I. et al., 1980; Jones \& Melling, 1984). For example, the reduced recombinational efficiency of $\mathrm{rec} A$ strains would be expected to lead to plasmids being more stable in such hosts (Summers \& Sherratt, 1984).

\footnotetext{
$\dagger$ Present address: Apcel Ltd, 244-250 Bath Road, Slough, Berkshire SL1 4DY, UK.
} 
The environmental conditions in which plasmid-bearing cells are grown are also known to affect the segregational stability of the plasmid. Various plasmids have been found to be unstable in $E$. coli grown in continuous culture with glucose, phosphate or magnesium limitations (Godwin \& Slater, 1979; Jones, I. et al., 1980; Noack et al., 1981; Jones \& Melling, 1984). However, nitrogen limitation has been observed to have little influence on the stability of pBR325 (Roth et al., 1980; Wouters et al., 1980; Noack et al., 1981). Wouters et al. (1980) reported that low growth rates or high growth temperatures reduced the stability of $E$. coli (pBR322) in continuous culture. Considerable plasmid-specific variation has been recorded, and it is apparent that the interactions of all the variables is, as yet, incompletely understood.

Other factors which would be expected to influence the segregational stability of a plasmid in E. coli include properties of the plasmid itself (Inselburg, 1978; Skogman et al., 1983; Jones \& Melling, 1984). For example, most naturally occurring plasmids have a complex mechanism to control copy number (Molin et al., 1981; Som \& Tomizawa, 1983) and, in the case of low copy number plasmids, one or more sequences which ensure the efficient partitioning of plasmid DNA molecules at cell division (Meacock \& Cohen, 1980). However, some plasmids designed specifically for use as recombinant DNA cloning vectors, particularly those based on a ColEl replicon, e.g. pAT153, have lost elements involved in both replication control (Twigg \& Sherratt, 1980) and plasmid partitioning (Primrose et al., 1984; Skogman et al., 1983). Furthermore, sequence alteration may affect plasmid segregational stability (Jones \& Melling, 1984), as may the presence of genes coding for heterologous proteins.

Bacterial systems which are to be used to produce heterologous proteins on a production scale must be stable over many generations. It is, therefore, valuable to understand the causes of plasmid instability and, where possible, to design a system which avoids those features likely to lead to the loss of the expressing plasmid.

This paper describes the effect of expression of the Met-prochymosin gene on the stability of various plasmid constructs in $E$. coli. A plasmid which demonstrates complete segregational stability and is able to express the Met-prochymosin gene at high levels is described.

\section{METHODS}

Bacterial strains and plasmids. The $E$ coli K12 strains RV308 and HB101 (Pro- Leu $^{-} \mathrm{B}_{1} \mathrm{Str}^{\mathrm{r}} \mathrm{RecA}^{-}$) (Boyer \& Roulland-Dussoix, 1969) were transformed with appropriate plasmids and maintained on L-agar supplemented with carbenicillin. The plasmids studied were pAT153 (Twigg \& Sherratt, 1980), pCT54, pCT66, pCT70 (Emtage et al., 1983), and pMG420b, pMG424b, pMG165 and pMG168 (Department of Microbial Genetics, Celltech Ltd).

Media. For starter cultures, L-agar supplemented with carbenicillin $\left(0 \cdot 1 \mathrm{~g} \mathrm{l}^{-1}\right)$ and L-broth supplemented with tryptophan $\left(0 \cdot 1 \mathrm{~g} \mathrm{l}^{-1}\right)$ were used. For growth of $E$. coli RV308 in chemostats, a defined salts medium designed to give carbon limitation was used: it comprised glucose, $4 \mathrm{~g} \mathrm{l}^{-1} ;\left(\mathrm{NH}_{4}\right)_{2} \mathrm{SO}_{4}, 5 \mathrm{~g} \mathrm{l}^{-1}$; phosphate buffer and a trace element solution (Pirt, 1975). For growth of $E$. coli HB101 in chemostats the defined salts medium was supplemented with proline, $200 \mathrm{mg} \mathrm{l}^{-1}$; leucine, $100 \mathrm{mg} \mathrm{l}^{-1}$ and thiamin, $10 \mathrm{mg} \mathrm{l}^{-1}$. For both strains, the medium was supplemented with tryptophan, $100 \mathrm{mg} \mathrm{l}^{-1}$, unless otherwise stated. Antifoam (polypropylene glycol 2000) was present in the medium at $0.001 \%(\mathrm{v} / \mathrm{v})$.

Chemostat experiments. For continuous culture experiments, cells were grown in 1 litre LH500 series fermenter vessels ( $\mathrm{LH}$ Engineering) at $30^{\circ} \mathrm{C}$ or $37^{\circ} \mathrm{C}$, and the $\mathrm{pH}$ was maintained at 6.5 by the addition of $3 \mathrm{M}-\mathrm{NaOH}$. The fermenters were stirred continuously at 700 r.p.m. and aerated with one volume of air per culture volume per minute. The dissolved oxygen tension did not fall below $50 \%$ saturation. Using the defined salts media described above, cells were grown under glucose limitation (all other nutrients being in excess) at a dilution rate $(D)$ of approximately $0 \cdot 16 \mathrm{~h}^{-1}$.

A single colony of the chosen strain of $E$. coli, carrying the appropriate plasmid, was taken from an agar plate containing carbenicillin and inoculated into $100 \mathrm{ml} \mathrm{L}$-broth in a $250 \mathrm{ml}$ conical flask with a steel spring baffle. The culture was incubated on an orbital shaker $\left(30^{\circ} \mathrm{C}\right.$ or $37^{\circ} \mathrm{C}, 240$ r.p.m. $)$ until stationary phase was reached. The cells were harvested by centrifugation $\left(7000 \mathrm{~g}, 20^{\circ} \mathrm{C}, 10 \mathrm{~min}\right)$, resuspended in sterile defined medium minus glucose and inoculated into a 1 litre fermenter vessel containing defined medium. When the culture reached an optical density at $600 \mathrm{~nm}$ of at least $60 \%$ of the maximum supported by the medium, the pump was turned on and the system run as a chemostat.

When the total biomass in the fermenter was constant, it was assumed that the initial transient growth phase had ceased. Thereafter the number of generations in the steady state was calculated. 
(a)
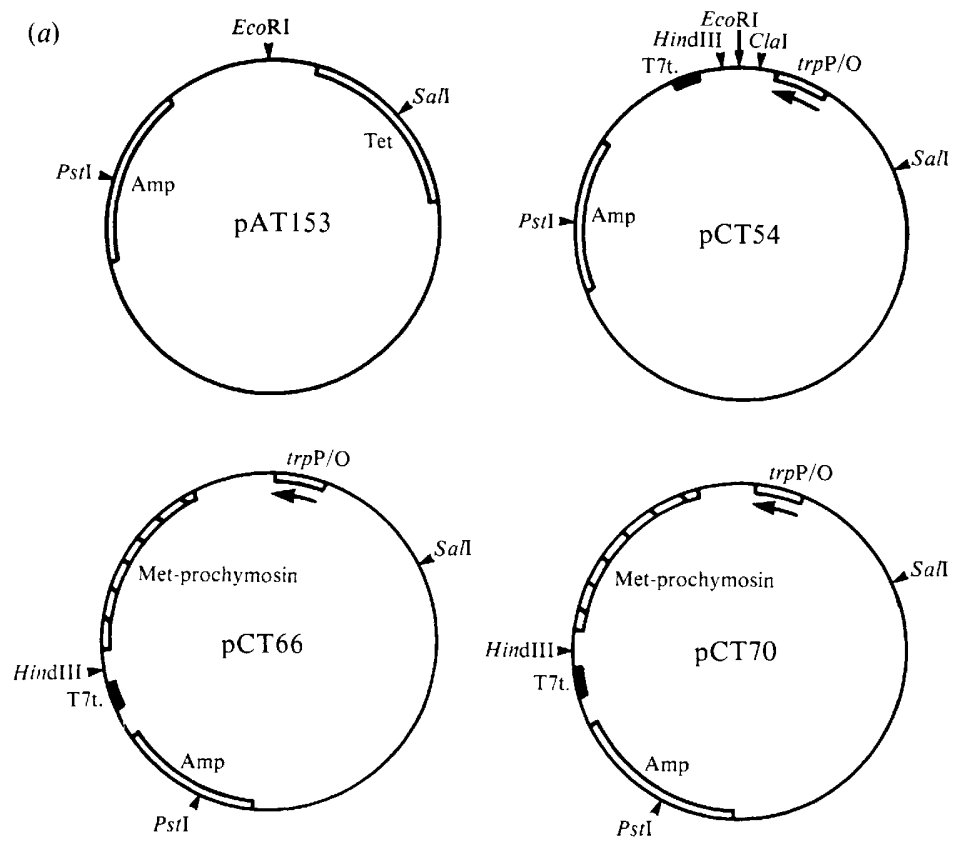

(b)

\section{pCT54 AAGGGTATCGATTGATCA ATG AATTCCAAGCTT \\ pCT66 AAGG GTATCGATTGATCA ATG -prochymosin \\ pCT70 AAGG GTAT TTGATCA ATG -prochymosin}

Fig. 1. (a) Simplified maps showing the derivation of plasmids pCT54, pCT66 and pCT70; $(b)$ the Shine-Dalgarno to ATG region of pCT54, pCT66 and pCT70. T7t., T7 terminator.

Antibiotic resistance test. Samples were withdrawn from the continuous cultures, diluted and plated onto L-agar. One hundred single colonies were picked onto both L-agar containing carbenicillin and L-agar as a control. The number of colonies resistant to the antibiotic was expressed as a percentage of the number growing on the L-agar and was taken to represent the proportion of the population which carried the plasmid.

Western blotting procedure. Proteins were electrophoresed through a $10 \%(w / v)$ acrylamide gel (Tris/glycine/ SDS) and transferred to nitrocellulose using a BRL Transblot apparatus. The blotting protocol and immunological detection were done using procedures described by Twobin et al. (1979) and Burnette (1980).

Agarose gels. DNA was extracted from culture samples standardized for cell density and electrophoresed on $0.7 \%$ agarose gels as described by Maniatis et al. (1982). All chemostat cultures investigated were analysed in this way, to confirm that no gross alteration in the plasmid had occurred. It was found that all the plasmids remained unaltered during the time in which they were to be found in E. coli.

\section{RESULTS}

Stability of pCT70 and related plasmids in continuous culture

The plasmid pCT70 (Fig. 1), an intermediate copy number plasmid (40-60 copies per host chromosome), expresses the bovine gene for prochymosin, preceded by a methionine residue (Met-prochymosin), from the $\operatorname{trp}$ promoter to yield up to approximately $5 \%$ of total cell protein (Emtage et al., 1983). E. coli HB101(pCT70), when grown in the absence of antibiotic selection, proved to be extremely unstable in defined medium, and plasmid-free segregants arose at a very high frequency, whereas pCT70 was present in $100 \%$ of the population after growth in complex medium. The plasmid was rapidly lost from the host cells during the batch culture phase in defined medium, and during the subsequent transient stage after the pump was turned on (Fig. 3). A steady state could not be established with E. coli HB101(pCT70). Although the medium contained added tryptophan $\left(100 \mathrm{mg} \mathrm{l}^{-1}\right)$, the Met-prochymosin gene was still efficiently 

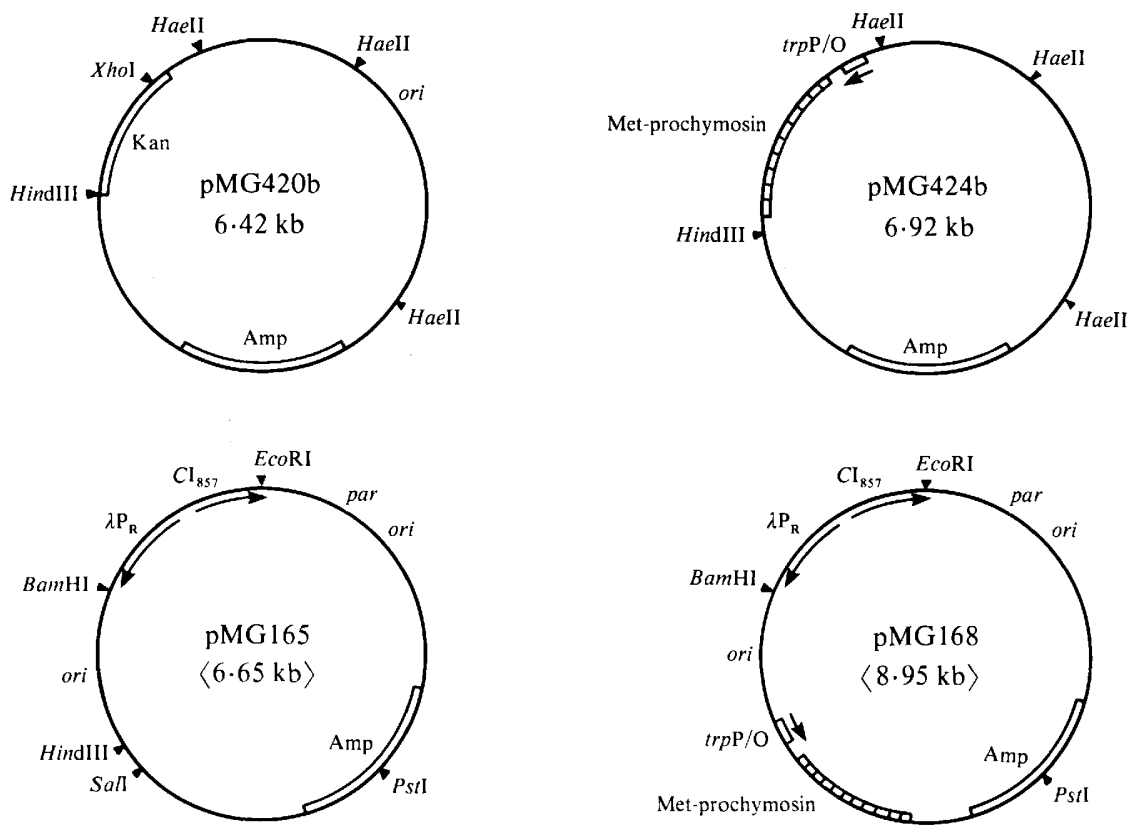

Fig. 2. Simplified maps of plasmids pMG420b, pMG424b, pMG165 and pMG168.

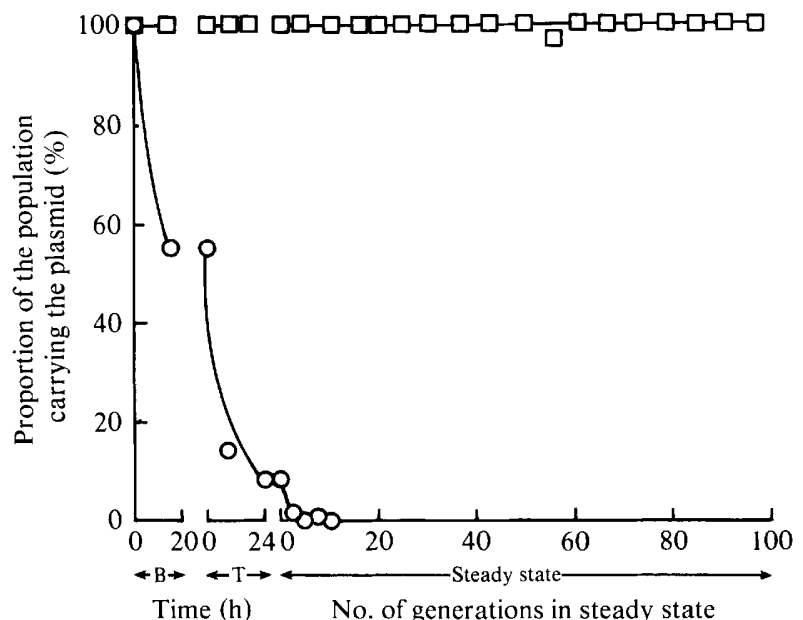

Fig. 3. Stability of E. coli $\mathrm{HB} 101$ (pCT70) and E. coli $\mathrm{HB} 101$ (pAT153) grown in continuous culture with glucose limitation $\left(D=0.16 \mathrm{~h}^{-1}, \mathrm{pH} 6.5,37^{\circ} \mathrm{C}\right)$. After inoculation into the fermenters the cells were grown initially in batch culture (B). The pump was switched on and, after a transient phase (T), steady state (constant biomass) was achieved. Samples were taken and the proportion of the population expressing the plasmid was determined. O, E. coli(pCT70); $\square$, E. coli(pAT153).

expressed (Fig. 4) from the trp promoter, suggesting that this promoter cannot be tightly controlled on a multi-copy plasmid in the presence of only the chromosomal trp repressor. Repetition of this experiment on several occasions gave consistent results.

The stability of the parent replicon pAT153 was also investigated in E. coli HB101 grown in glucose-limited continuous culture. The plasmid was found to be stable, not only during the initial phases in the fermenter, but for more than 80 generations in chemostat culture (Fig. 3). 


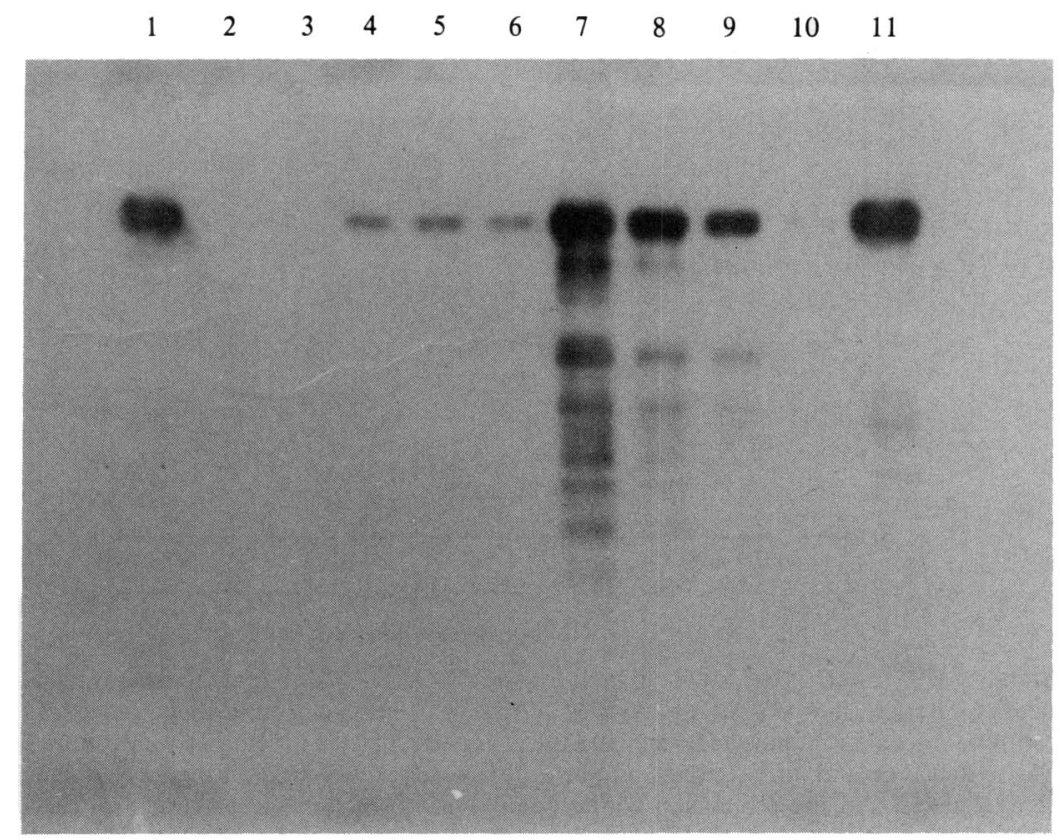

Fig. 4. Analysis of Met-prochymosin expression levels in E. coli HB101 carrying pCT66 or pCT70. Samples were removed from the fermenters and analysed by Western blotting. Tracks contain: 1 , prochymosin st: Lard: 2, pCT66 after 4 generations (+tryptophan); 3, pCT66 after 16 generations (+tryptoph..1); 4, pCT66 after 55 generations (-tryptophan); 5, pCT66 after 73 generations (-tryptophan); 6, pCT66 after 95 generations ( - tryptophan); 7, pCT70 on inoculation (batch phase); 8 , pCT70 after $20 \mathrm{~h}$ (batch phase); 9, pCT70 after $28 \mathrm{~h}$ (transient phase); 10 , pCT70 after $48 \mathrm{~h}$ (transient phase); II, prochymosin standard. All pCT70 samples were taken from cells growing in the presence of tryptophan $\left(0 \cdot 1 \mathrm{~g} \mathrm{I}^{-1}\right)$.

This result suggests that the instability of pCT70 is due to the changes in plasmid structure effected during the modification of pAT153. In order to investigate this further, the stability of two plasmids formed during the construction of pCT70 was determined.

pCT54 (Fig. 1) carries the trp promoter sequence with, a few base pairs downstream of this, a T7 transcription terminator. As with pAT153, pCT54 was found to be stable in E. coli HB101 through all the phases of growth, including approximately 45 generations in continuous culture in medium containing tryptophan (results not shown). Further, when tryptophan was removed from the growth medium, which results in transcription from the trp promoter, the plasmid was maintained in the entire cell population throughout a further 50 generations. Thus, insertion of the strong trp promoter, coupled with the T7 terminator, did not destabilize pAT153.

In order to express the protein at high levels in E. coli, the gene for Met-prochymosin was inserted into the expression vector, pCT54, between the trp promoter and the T7 terminator, giving the plasmid pCT66 (Fig. 1). Levels of expression of Met-prochymosin in E. coli(pCT66) were so low as to be undetectable on polyacrylamide gels, and could only just be detected by Western blot analysis (Fig. 4). The number of base pairs between the Shine-Dalgarno sequence (SD) and the ATG translational start codon of pCT66 was longer than is usually observed in E. coli (14 nucleotides as opposed to the more usual 6-11: Gold et al., 1981). This distance was, therefore, reduced by S1 nuclease digestion to give plasmid pCT70 (Fig. 1), which had an SD to ATG distance of $11 \mathrm{bp}$, and which gives high levels of Met-prochymosin expression (Fig. 5) (Emtage et al., 1983).

As with pCT54, pCT66 was stable through batch and transient stages in the fermenter and for at least 45 generations of growth in continuous culture in the presence of tryptophan. In the absence of added tryptophan, when Met-prochymosin was expressed at low levels (Fig. 4), 


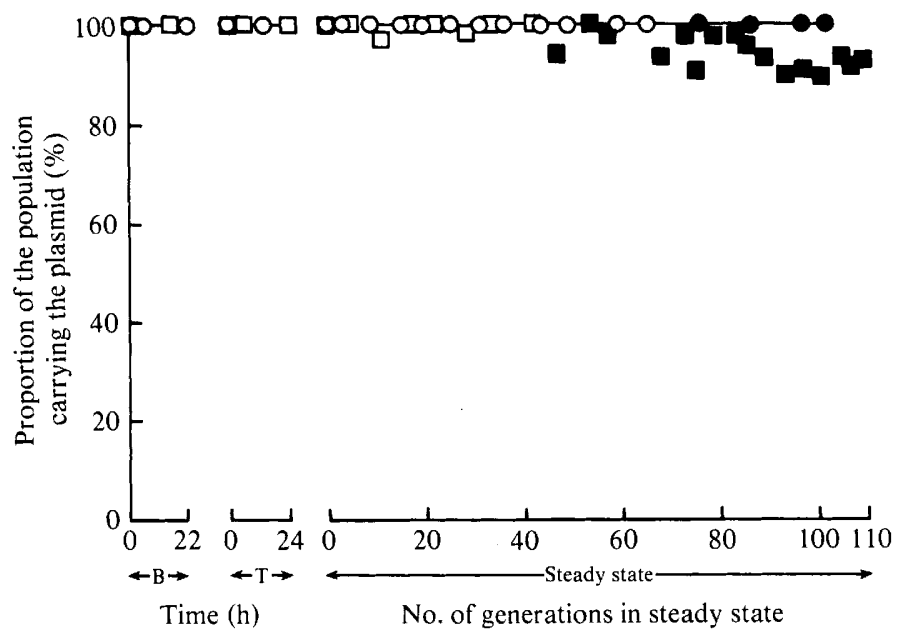

Fig. 5. Stability of E. coli RV308(pMG420b) and $E$. coli RV308(pMG424b) grown in continuous culture with glucose limitation $\left(D=0 \cdot 16 \mathrm{~h}^{-1}, \mathrm{pH} 6.5,30^{\circ} \mathrm{C}\right)$ in the presence and absence of added tryptophan $\left(0 \cdot 1 \mathrm{~g} \mathrm{l}^{-1}\right)$. After inoculation into the fermenters the cells were initially grown in batch culture (B). The pump was switched on and, after a transient phase $(T)$, steady state (constant biomass) was achieved. Samples were taken and the proportion of the population expressing the plasmid was determined. $E$. coli(pMG420b) in the presence $(O)$ and absence $(O)$ of tryptophan; $E$. coli(pMG424b) in the presence $(\square)$ and absence $(\square)$ of tryptophan.

pCT66 remained stable for at least a further 50 generations in the chemostat (data not shown). The data obtained with pCT66 in both the presence and absence of tryptophan suggest that neither transcription nor low level translation of the Met-prochymosin gene leads to plasmid instability.

\section{Growth of cells containing $p C T 54, p C T 66$ or $p C T 70$}

Plasmids have been shown to affect the maximum specific growth rate $\left(\mu_{\max }\right)$ of $E$. coli in complex, and in defined, media (Zund \& Lebek, 1980). Therefore, batch culture experiments were done to determine the $\mu_{\max }$ of $E$. coli $\mathrm{HB} 101$ carrying pCT54, pCT66 or pCT70. All strains were grown overnight in conical flasks containing L-broth (see Methods). These cultures were used to inoculate further flasks containing L-broth or the defined medium used in the chemostat studies. The proportion of the population carrying the plasmid in the stationary phase of the first L-broth culture, the defined medium culture and the second L-broth culture was determined.

In all cases, the plasmids were $100 \%$ stable in the initial L-broth culture, as was always observed with the starter cultures in L-broth for the chemostat experiments. The stability of the various plasmids in the second L-broth culture and the defined medium batch culture reflected the results observed in continuous culture (Table 1). Further, when E. coli HB101(pCT70) was grown in batch culture in either complex or defined media, the $\mu_{\max }$ of the organism was reduced by $30-35 \%$ as compared with the plasmid-free host (Table 1 ). In contrast, the presence of pCT54 or pCT66 in E. coli $\mathrm{HB} 101$ did not reduce the growth rate of the host organism.

\section{Stability of low copy number plasmids expressing Met-prochymosin}

Plasmid pAT153 and its derivatives pCT54, pCT66 and pCT70 are present in E. coli at intermediate copy numbers of approximately 40-60 per chromosome (Emtage et al., 1983). Expression of the Met-prochymosin gene in pCT70 is clearly responsible, at least in part, for the instability of the plasmid, so it was decided to investigate the stability of a low copy number plasmid expressing Met-prochymosin. 
Table 1. Growth rates of E. coli HBIOI carrying various plasmids when grown in shake flasks in either complex or defined media

All experiments were done at least three times with the exception of pCT70 in defined medium, which was only done once. Results did not vary by more than $10 \%$.

\begin{tabular}{lcccc} 
Plasmid & \multicolumn{2}{c}{ Complex medium* } & \multicolumn{2}{c}{ Defined medium } \\
\cline { 2 - 3 } present & $\overbrace{\mu_{\max }\left(\mathrm{h}^{-1}\right)}$ & Stability $(\%) \dagger$ & $\overbrace{\mu_{\max }\left(\mathrm{h}^{-1}\right)}^{\text {Stability }(\%)})^{\dagger}$ \\
None & 0.788 & - & 0.336 & - \\
pCT54 & 0.763 & 100 & 0.328 & 100 \\
pCT66 & 0.757 & 100 & 0.331 & 100 \\
pCT70 & 0.508 & 88 & $0.240 \ddagger$ & 29
\end{tabular}

${ }^{*}$ L-broth with $0 \cdot 1 \mathrm{~g}$ tryptophan $1^{-1}$

$\dagger$ All cultures were started from L-broth cultures, which were $100 \%$ plasmid bearing. The proportion of the population carrying the plasmid in early stationary phase is recorded here.

$\ddagger \mu_{\mathrm{m} i \mathrm{r}}$ calculated in early exponential phase when the proportion of the population carrying the plasmid was greater than $95 \%$.

Plasmid pMG420b (Fig. 2) was derived from the low copy number plasmid pHSG415 (Hashimoto-Gotoh et al., 1981). The temperature sensitive origin of replication of pHSG415 has been replaced with the origin of replication and par sequence from plasmid pSC101 (the original parent of pHSG415: Hashimoto-Gotoh et al., 1981). In order to express Met-prochymosin from this plasmid, the Met-prochymosin fragment of pCT70 was inserted into the kanamycin resistance gene. This gave plasmid pMG424b (Fig. 2), in which the Met-prochymosin gene is expressed from the trp promoter.

The stability of both pMG420b and pMG424b in E. coli RV308 when grown in continuous culture with glucose limitation was investigated. E. coli RV308(pMG420b) was stable for over 60 generations in the presence of added tryptophan and for at least a further 35 generations in the absence of tryptophan (Fig. 5). E. coli RV308(pMG424b) was found on two separate occasions to be approximately $99 \%$ stable for 45 generations when grown in continuous culture in the presence of tryptophan. During further growth, in the absence of tryptophan, the proportion of the bacterial population carrying the plasmid fell from $99 \%$ to $93 \%$ over 65 generations. This change in stability of the plasmid may have resulted from an increase in the levels of expression of Met-prochymosin. However, Met-prochymosin was detected in cells removed from the culture growing in both the presence and absence of tryptophan (Fig. 6), and the levels did not appear to be markedly different.

\section{Amplifiable system expressing Met-prochymosin}

The instability of plasmids carrying the Met-prochymosin gene would appear to be associated with expression of the gene, rather than its actual presence in a plasmid. Therefore, to maintain stability a Met-prochymosin expressing plasmid of high or intermediate copy number in $E$. coli requires that expression of the gene is switched off. The lac operator on a multicopy plasmid cannot be fully controlled when only the chromosomal repressor gene is available (O'Farrell et al., 1978; Lee \& Bailey, 1984). Similarly, the trp promoter may be inadequately controlled on a plasmid such as pCT70. It is of considerable importance, therefore, either to find a more completely controlled promoter system, or to maintain the plasmid at a very low copy number. However, to express Met-prochymosin from two to three copies of the gene is unlikely to yield a sufficiently high level of the protein to form a commercially viable production process. An important feature of a successful system would be significant gene amplification, either throughout the entire process (as with pCT70) or at a specific stage in the fermentation (Larsen et al., 1984).

Such a controlled system was therefore designed (Yarranton et al., 1984; E. M. Wright and coworkers, unpublished results). It was based on the requirement for a plasmid which could both be maintained stably, and also express high levels of Met-prochymosin. The basic cloning 


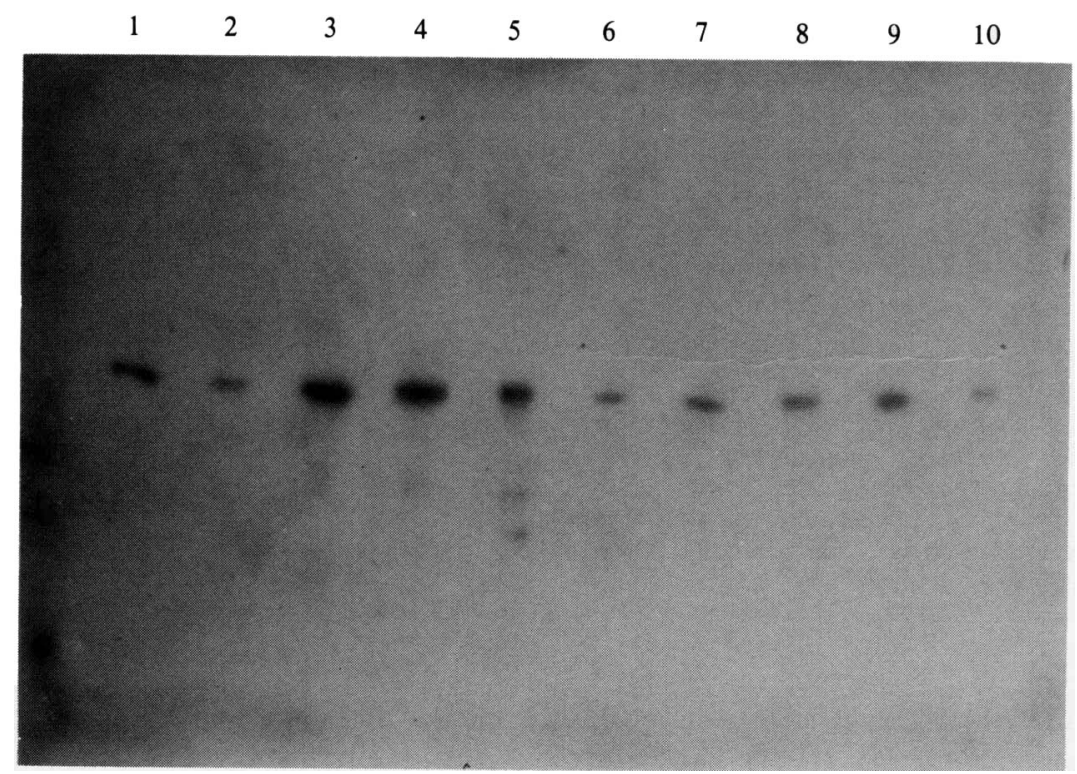

Fig. 6. Analysis of Met-prochymosin expression levels in E. coli R V308 carrying pMG424b or pMG 168 . Samples were removed from continuous cultures and analysed by Western blotting. Tracks contain: 1 , prochymosin standard; 2, pMG424b after 18 generations (+tryptophan); 3, pMG424b after 40 generations (+tryptophan); 4, pMG424b after 64 generations (-tryptophan); 5, pMG424b after 84 generations (-tryptophan); 6, pMG168 after 21 generations (+tryptophan); 7, pMG168 after 42 generations (+tryptophan); 8, pMG168 after 68 generations (-tryptophan); 9, pMG168 after 83 generations (-tryptophan); 10, prochymosin standard.

vector, pMG165, included the pSC101 origin of replication and its par sequence, the $c \mathrm{I} 857 \lambda$ repressor gene, the $\lambda P_{R}$ promoter and, downstream from this, the pAT153 origin of replication, minus its normal promoter sequence (Fig. 2). The design of the vector ensures that, at $30^{\circ} \mathrm{C}$, the pSC101 origin of replication alone can function. Thus, at $30^{\circ} \mathrm{C}$, the plasmid will be present at very low copy number, because the pAT153 origin will be switched off due to the action of the $\lambda$ repressor protein on the $\lambda \mathrm{P}_{\mathrm{R}}$ promoter. However, at $42^{\circ} \mathrm{C}$, the $c 1857$ gene product is denatured and the $\lambda \mathrm{P}_{\mathrm{R}}$ promoter can function, leading to a dramatic increase in the level of replication and, therefore, the copy number of the plasmid (Fig. 7).

Insertion of the trp promoter and the Met-prochymosin fragment from pCT70 into pMG165, downstream from the pAT153 origin, using the HindIII and Sall sites, gave plasmid pMG168 (Fig. 2). At $30^{\circ} \mathrm{C}$ the plasmid was maintained at very low copy number, whereas at $42^{\circ} \mathrm{C}$ there was a 50-fold amplification of the plasmid genome (Fig. 7). The expression of Met-prochymosin responded in a similar manner (results not shown; E. M. Wright and co-workers, unpublished results).

To satisfy the criteria for a successful production system, it was necessary to determine whether pMG 168 was stable in $E$. coli over a significant period of time. The stability of $E$. coli RV308 containing pMG165 or pMG168 was investigated in continuous culture with glucose limitation, as described above. Both plasmids were $100 \%$ stable for 70 generations in the presence of tryptophan and for at least 45 generations in the absence of tryptophan (data not shown). Samples were taken from the E. coli RV308(pMG168) culture growing in the presence and absence of tryptophan, and Met-prochymosin levels determined by Western blot analysis. Cultures growing in both the presence and absence of tryptophan expressed very low levels of Met-prochymosin (Fig. 6). However, this did not appear to affect the stable maintenance of the plasmid in the culture. 


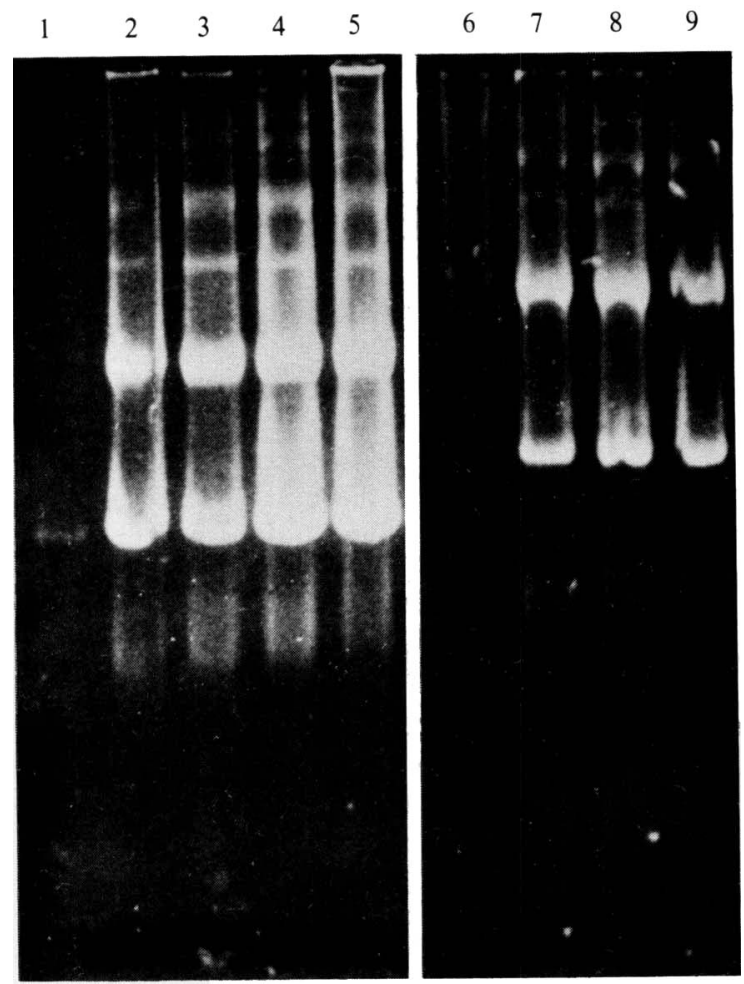

Fig. 7. Agarose gel to show increase in plasmid copy number after temperature induction of $E$. coli R V308(pMG 165) and E. coli R V308(pMG 168). Samples were removed from continuous cultures before and after the temperature was increased from $30^{\circ} \mathrm{C}$ to $42^{\circ} \mathrm{C}$. Both cultures were growing at $D=0.16 \mathrm{~h}^{-1}, T_{\mathrm{d}}=4.33 \mathrm{~h}$. Tracks contain: 1 , pMG 165 at $30^{\circ} \mathrm{C} ; 2, \mathrm{pMG} 165,3.5 \mathrm{~h}$ at $42^{\circ} \mathrm{C} ; 3$, pMG 165,8 h at $42^{\circ} \mathrm{C} ; 4$, pMG $165,11.5$ h at $42^{\circ} \mathrm{C} ; 5$, pMG $165,17.5 \mathrm{~h}$ at $42{ }^{\circ} \mathrm{C} ; 6$, pMG 168 at $30^{\circ} \mathrm{C} ; 7$, pMG $168,3.5 \mathrm{~h}$ at $42^{\circ} \mathrm{C} ; 8, \mathrm{pMG} 168,8 \mathrm{~h}$ at $42^{\circ} \mathrm{C} ; 9$, pMG $168,11.5 \mathrm{~h}$ at $42^{\circ} \mathrm{C}$.

\section{DISCUSSION}

The instability of plasmid pCT70 in E. coli is related to the high level of expression of the Metprochymosin gene. This leads to two, sequential effects, namely the occurrence of plasmid-free cells and the subsequent dominance of the total cell population by the plasmid-free strain (Caulcott, 1984). It is demonstrated in this paper that E. coli carrying a plasmid which does not express Met-prochymosin at high levels has a significant growth advantage over those cells which synthesize large amounts of the protein. This may be the result of the demands made on the cellular protein synthetic machinery, including ribosomes and tRNA pools. It is not surprising that, under such circumstances, a population of E. coli(pCT70) growing in the absence of selection does not display $100 \%$ retention of the plasmid.

It is apparent, however, that $E$. coli is able to absorb into its cellular make-up low levels of Met-prochymosin without apparent stress on the cellular metabolism which would be expected to lead to the occurrence of plasmid-free cells. This is demonstrated by the stability in E. coli of pCT66, pMG424b and pMG168. In these cultures the very gradual reduction in the percentage of the bacterial population which is plasmid-bearing suggests that plasmid-free cells, once generated, do not have a significant growth advantage over plasmid-bearing cells (Walmsley et al., 1983; Caulcott, 1984).

The data presented here clearly demonstrate the leakiness of the trp promoter. It has been observed previously (O'Farrell et al., 1978; Lee \& Bailey, 1984) that metabolic promoters such as the lac promoter are not necessarily easily controlled when present on high copy number 
systems. This is seen with E. coli $\mathrm{HB} 101$ (pCT70), where the many trp promoters probably titrate out the trp repressor-tryptophan complex which would normally switch off the promoter. Nonetheless, the trp promoter will influence the expression of heterologous genes under certain circumstances. This was demonstrated in the continuous cultures of E. coli(pCT66), where the level of expression of Met-prochymosin was dependent on not adding tryptophan to the medium. Tryptophan addition caused transcription from the trp promoter to be either very much reduced or even switched off.

Both pAT153 and pBR322 (unpublished data) were found to be stable in E. coli, results which contrast with those of several other workers (e.g. Wouters et al., 1980; Jones, I. et al., 1980; Primrose et al., 1982; Jones \& Melling, 1984). Derivatives of pAT153, namely pCT54 and pCT66, were also stable. The differences observed between previous data and those presented here emphasize the influence of factors such as growth conditions and host strain on plasmid stability. It is not possible to state that a specific plasmid is 'segregationally stable' unless the host strain and the physiological condition are defined at the same time. More work will have to be done to investigate extensively the importance of such factors on the relationship between a plasmid and its host.

Many features of the plasmid pMG165 and its derivatives need to be studied, in particular, the relationship between the increase in plasmid copy number and the increase in gene product. It will be important to understand the relative metabolic controls, and burdens, of both events in order best to utilize the system to obtain high levels of expression of recombinant gene products. It has already been demonstrated that this amplifiable vector system can be successfully induced at high biomass in $150 \mathrm{l}$ scale fermentations. It is anticipated that with a greater understanding of the system, a valuable production process can be developed.

We are grateful to Dr John Birch, Dr Gwyn Humphreys and Dr Malcolm Rhodes for helpful advice and discussions, to Heather Robertson for technical assistance and to Margaret Turner for secretarial assistance.

\section{REFERENCES}

Boyer, H. W. \& Roulland-Dussoix, D. (1969). A complementation analysis of the restriction and modification of DNA in Escherichia coli. Journal of Molecular Biology 41, 459-472.

BURNETTE, W. N. (1980). Electrophoretic transfer of proteins from sodium dodecyl sulfate-polyacrylamide gels to unmodified nitrocellulose and radiographic detection with antibody and radioiodinated protein A. Analytical Biochemistry 112, 195-205.

Carrier, M. J., Nugent, M. E., Tacon, W. C. \& Primrose, S. B. (1983). High expression of cloned genes in $E$. coli and its consequences. Trends in Biotechnology 1, 109-113.

Caulcott, C. A. (1984). Competition between plasmid-positive and plasmid-negative cells. Biochemical Society Transactions 12, 1140-1142.

Emtage, J. S., Angal, S., Doel, M. T., Harris, T. J. R., Jenkins, B., Lilley, G. \& Lowe, P. (1983). Synthesis of calf prochymosin (prorennin) in Escherichia coli. Proceedings of the National Academy of Sciences of the United States of America 80, $367 \mathrm{i}-3675$.

Godwin, D. \& Slater, J. H. (1979). The influence of the growth environment on the stability of a drug resistance plasmid in Escherichia coli $\mathrm{K} 12$. Journal of General Microbiology 111, 201-210.

Goeddel, D. V., Heynecker, H. L., Hozumi, T., Arentzen, R., Itakura, K., Yansura, D. G., Ross, M. J., Miozzari, G., Crea, R. \& Seeburg, P. H. (1979). Direct expression in Escherichia coli of a DNA sequence coding for human growth hormone. Nature, London 281, 544-548.
Gold, L., Pribnow, D., Schneider, T., Shinedling, S., Singer, B. S. \& Stormo, G. (1981). Translational initiation in prokaryotes. Annual Review of Microbiology 35, 365-403.

Hashimoto-Gotoh, T., Franklin, F. C. H., NordHeim, A. \& Timmis, K. N. (1981). Specific purpose plasmid cloning vectors. 1. Low copy number temperature sensitive, mobilisation defective pSCl01-derived containment vectors. Gene 16, 227235.

Imanaka, T., Tsunekawa, H. \& Aiba, S. (1980). Phenotypic stability of trp operon recombinant plasmids in Escherichia coli. Journal of General Microbiology 1181, 253-26l.

INSELBURG, J. (1978). ColEl plasmid mutants affecting growth of an $E$. coli $r e c B$ rec $A s b c B$ mutant. Journal of Bacteriology 133, 433-436.

Jones, I. M., Primrose, S. B., Robinson, A. \& Ellwood, D. C. (1980). Maintenance of some ColEl-type plasmids in chemostat culture. Molecular and General Genetics 180, 579-584.

Jones, S. A. \& Melling, J. (1984). Persistence of pBR322-related plasmids in Escherichia coli grown in chemostat culture. FEMS Microbiology Letters 22, 239-243.

Jones, S. A., Dearnley, K., Bennett, P. M. \& Melling, J. (1980). The stability of antibiotic resistance plasmids in Escherichia coli hosts grown in continuous culture. Society for General Microbiology Quarterly 8, 44.

Larsen, J. E. L., Gerdes, K., Light, J. \& Molin, S. (1984). Low-copy-number plasmid-cloning vectors 
amplifiable by derepression of an inserted foreign promoter. Gene 28, 45-54.

LeE, S. B. \& BaILeY, J. E. (1984). Genetically structured models for lac promoter-operator function in the Escherichia coli chromosome and in multicopy plasmids: lac operator function. Biotechnology and Bioengineering 26, 1372-1382.

Maniatis, T., Fritsch, E. F. \& Sambrook, J. (1982). Molecular Cloning: A Laboratory Manual. Cold Spring Harbor, New York: Cold Spring Harbor Laboratory.

Meacock, P. A. \& Cohen, S. N. (1980). Partitioning of bacterial plasmids during cell division: a cis-acting locus that accomplishes stable plasmid inheritance. Cell 20, 529-542.

MiwA, K. \& Momose, H. (1982). Micro-organisms harbouring a plasmid, with stabilised characteristics, and a method of obtaining it. European Patent Application no. 0019877-A1.

Molin, S., Stougaard, P., Light, J., Nordstrom, M. \& Nordstrom, K. (1981). Isolation and characterisation of new copy number mutants of plasmid RI and identification of a polypeptide involved in copy number control. Molecular and General Genetics 181, 123-130.

Noack, D., Roth, M., Geuther, R., Muller, G. \& UNDISZ, K. (1981). Maintenance and genetic stability of vector plasmids pBR322 and pBR325 in Escherichia coli $\mathrm{K} 12$ strains grown in a chemostat. Molecular and General Genetics 184, 121-124.

O'Farrell, P. H., Polisky, B. \& Gelfand, D. H. (1978). Regulated expression by read through translation from a plasmid-encoded $\beta$-galactosidase. Journal of Bacteriology 134, 645-654.

Pennica, D., Holmes, W. E., Kohr, W. J., Harkins, R. N., Vehar, G. A., Ward, C. A., Bennett, W. F., Yelverston, E., SeeburG, P. H., Heyneker, H. L., Goeddel, D. V. \& Collen, D. (1983). Cloning and expression of human tissue-type plasminogen activator cDNA in E. coli. Nature, London 301, 214-22l.

PIRT, S. J. (1975). Principles of Microbe and Cell Cultivation, p. 134. Oxford: Blackwell Scientific Publications.

Primrose, S. B., Derbyshire, P., Jones, I. M., Robinson, A. \& Ellwood, D. C. (1984). The application of continuous culture to the study of plasmid stability. In Continuous Culture 8, pp. 213238. Edited by A. C. R. Dean, D. C. Ellwood \& C. G. T. Evans. Chichester: Ellis Horwood.

Roth, M., Muller, G. \& Noack, D. (1980). Loss of the multicopy resistance plasmid pBR325 from Escherichia coli GY2354 pBR325 during continuous cultivation. In Antibiotic Resistance, p. 143. Edited by S. Mitsuhashi, L. Rosnal \& V. Kremery. Prague: Avicenuma/Springer-Verlag.

Skogman, G., Nilsson, J. \& Gustafsson, P. (1983). The use of a partition locus to increase stability of tryptophan-operon-bearing plasmids in Escherichia coli. Gene 23, 105-115.

Som, T. \& Tomizawa, J. U. (1983). Regulatory regions of ColEl that are involved in determination of plasmid copy number. Proceedings of the National Academy of Sciences of the United States of America 80, 3282-3286.

Steuber, D. \& Bujard, H. (1982). Transcription from efficient promoters can interfere with plasmid replication and diminish expression of plasmid specific gene. EMBO Journal 11, 1399-1404.

Summers, D. K. \& SherratT, D. J. (1984). Multimerization of high copy number plasmids causes instability: ColEl encodes a determinant essential for plasmid monomerization and stability. Cells 36, 1097-1103.

Twigg, A. J. \& Sherratt, D. (1980). Trans-complementable copy-number mutants of plasmid ColEl. Nature, London 283, 216-218.

Twobin, H., Staehlin, T. \& Gordon, J. (1979). Electrophoretic transfer of proteins from polyacrylamide gels to nitrocellulose sheets: procedure and some applications. Proceedings of the National Academy of Sciences of the United States of America 76, $4350-4354$.

Walmsley, R. M., Gardner, D. C. J. \& Oliver, S. G. (1983). Stability of a cloned gene in yeast grown in chemostat culture. Molecular and General Genetics 192, 361-365.

Wouters, J. T. M., Driehuis, F. L., Polaczek, P. J., van Oppenraay, M.-L. H. A. \& van ANDEL, J. G. 1980). Persistence of the pBR322 plasmid in Escherichia coli $\mathrm{K} 12$ grown in chemostat cultures. Antonie ian Leeuwenhoek 46, 353-362.

YarRanton, G. T., Wright, E., Robinson, M. K. \& Humphreys, G. O. (1984). Dual-origin plasmid vectors whose origin of replication is controlled by the coliphage lambda promoter $\mathrm{P}_{\mathrm{L}}$. Gene $\mathbf{2 8}, 293-$ 300.

ZUND, P. \& LEBEK, G. (1980). Generation timeprolonging $\mathrm{R}$ plasmids: correlation between increases in the generation time of Escherichia coli caused by $\mathrm{R}$ plasmids and their molecular size. Plasmid 3, 65-69. 